\title{
Persistent Toxic Substances in the Brazilian Amazon: Contamination of Man and the Environment
}

\author{
João Paulo M. Torres, ${ }^{a, *}$ José Lailson-Brito, ${ }^{a, b}$ Giselle C. Saldanha, ${ }^{a, d}$ Paulo Dorneles, ${ }^{a}$ \\ Cláudio Eduardo A. e Silva, ${ }^{a}$ Olaf Malm, ${ }^{a}$ Jean R. Guimarães, ${ }^{a}$ Antônio Azeredo, ${ }^{c}$ Wanderley R. Bastos, ${ }^{d}$ \\ Vera Maria F. da Silva, ${ }^{e}$ Anthony R. Martin, ${ }^{f}$ Luz Cláudio $^{g}$ and Steve Markowitz ${ }^{h}$ \\ ${ }^{a}$ Laboratório de Radioisótopos Eduardo Penna Franca, Centro de Ciências da Saúde,
} Universidade Federal do Rio de Janeiro, 21941-902 Rio de Janeiro-RJ, Brazil

${ }^{b}$ Departamento de Oceanografia e Hidrologia, Centro de Tecnologia e Ciências, Universidade do Estado do Rio de Janeiro, 20550-013 Rio de Janeiro-RJ, Brazil

${ }^{c}$ Faculdade de Farmácia, Universidade Estadual de Feira de Santana, 44031-460 Feira de Santana-BA, Brazil

${ }^{d}$ Laborarório de Biogeoquímica Ambiental Wolfgang C. Pfeiffer, Universidade Federal de Rondônia, 78900-500 Porto Velho-RO, Brazil

eLaboratório de mamíferos aquáticos, Instituto Nacional de Pesquisas da Amazônia, 69060-001 Manaus-AM, Brazil

${ }^{f}$ NERC Sea Mammal Research Unit, Gatty Marine Laboratory, University of St Andrews, St Andrews, Scotland

${ }^{g}$ Environmental Medicine Department, Mount Sinai School of Medicine, New York, USA

${ }^{h}$ Center for Biology of the Natural Systems, Queens College, New York, USA

O inseticida organoclorado DDT foi largamente utilizado no Brasil desde 1945, para fins agrícolas e no controle de vetores. Em 1986 foi proibida a sua utilização na agricultura e em 1997 esta proibição se estendeu também ao uso no controle de vetores. No entanto, a presença de DDT no meio urbano, solos florestais, leite materno e biota aquática ainda é comum especialmente na Amazônia. Os resultados obtidos desde meados dos anos 90 indicam que a contaminação ambiental com este pesticida ainda é relativamente alta. Devido ao elevado consumo de peixe pelas populações ribeirinhas tradicionais, o leite materno pode representar uma importante fonte de exposição ao DDT para os recém-nascidos. Novos resultados sobre DDT e PCB no golfinho vermelho (Inia geoffrensis), um mamífero aquático endêmico da Amazônia, também é relatada.

The organochlorine insecticide DDT was extensively used in Brazil since 1945, both for agricultural purposes and for vector control measures. In 1986 its uses were forbidden in agriculture and in 1997 it was also phased-out in vector controls programs. However, the presence of DDT in urban and forested soils, breast milk and aquatic biota is still common, especially at the Amazon region. The results gathered since the middle of the 90 s indicate that environmental contamination with this pesticide is still relatively high. Due to the high fish consumption by traditional riverside populations, human breast milk may represent an important source of DDT exposure to newborns. New results on DDT and PCBs in red dolphin (Inia geoffrensis), an endemic aquatic mammal of the Amazon region, is also reported.

Keywords: POPs, DDT, Amazon, Inia geoffrensis

\section{Introduction}

The organochlorine pesticide DDT is a well known chemical pesticide. Its efficacy in the combat of different

\footnotetext{
*e-mail: jptorres@biof.ufrj.br
}

agricultural pests, as well as in the control of disease vectors, have made DDT an icon of a golden era. The good and the bad in this case elicited a tremendous controversy that is present until today, recognized even in the texts/interpretations of various international legally binding instruments and global multilateral 
environmental agreements (e.g. The Basel and Stockholm Conventions). ${ }^{1}$

Although all of it's vectorial uses were suspended in Brazil since $1997,{ }^{2}$ our group has been documenting the environmental and food web contamination of the Amazon by analyzing samples we have collected since 1991. We have documented that DDT contamination is decreasing in fish tissues but is still very high in breast milk.

The overall issue of the protection of the rain forest is now under an extreme pressure mostly because the Brazilian government recently has decided to pave hundreds of $\mathrm{km}$ of roads in Para State in order to facilitate the expansion of the agricultural frontier (for cattle grazing and soy bean cultivation) and to construct new hydroelectric power ${ }^{3}$ plants to generate more energy for highly polluting mineral extraction in Rondonia State, as well as constructing a new gas pipeline that will cross Amazonas State.

Most of this development is desired as part of the overall modernization of the Brazilian economy. On the other hand, Brazil does not possess an adequate network system for environmental protection and it needs increase the number of skilled personal to built this protection system within Academias, Government Agencies and NGOs in order to help to understand and to minimize the impact such enterprises will have upon the natural ecosystems and its traditional population. This is a very important issue for the task force of the IPCP. Ever since the ecological movement appeared in the mid-1960s, the protection of the last and largest rain forest of the Planet has become important.

Based on recent data from our group as well as from other authors in Brazil and abroad, the burning of the forest to create pasture and for the production and exportation of soy-beans are releasing mercury and this is now recognized as one of the main sources of mercury to this fragile ecosystem.

Since mercury in its methylorganic form and all of the other persistent toxic substances biomagnify along the food chains, we believe that aquatic mammals (e.g. cetacean species), that are top predators in the aquatic environment, may be used as a good tool for environmental monitoring in the Amazon.

Two cetacean species occur in the Amazon Basin, the boto (Inia geoffrensis) and the tucuxi dolphin (Sotalia fluviatilis). This latter species is much smaller than the former. It is one of the smallest cetaceans, since adult tucuxi dolphins are up to $1.6 \mathrm{~m}$ in length. The tucuxi dolphin is a delphinid that is endemic to the rivers of the Amazon Basin. Concerning the boto, the currently accepted opinion regards the existence of only one species (Inia geoffrensis), with three subspecies: I. g. geoffrensis (occurring throughout the Amazon, except in the high Madeira River); I. g. boliviensis (occurring in the Madeira River above the Teotônio Falls) and I. g. humboltiana (occurring in the Orinoco River Basin). The species is classified into the Iniidae family and is morphologically very distinct from the other fluvial cetaceans mentioned. The size of adult botos ranges to $2.3 \mathrm{~m}$ (females) or $2.8 \mathrm{~m}$ (males). Although Inia geoffrensis and Sotalia fluviatilis are sympatric species, owing to its great flexibility the boto (I. geoffrensis) is able occupy flooded forest areas formed at the rainy season in the Amazonian region.

In Brazil scientists from the Rio de Janeiro Federal University, together with people from local and also from foreign universities have been studying this subject since middle of the 80's. At some places we have found a high prevalence of mercury and DDT contamination in humans, especially within the vast majority of riverine communities that rely almost exclusively on fish as their main source of animal protein.

\section{Experimental}

Abiotic materials (e.g. soils and river sediments) and biotic samples were collected at different parts of the Amazon region, especially in the Madeira River basin. The initial collection of fish and hair samples started at the beginning of the 90's in order to access $\mathrm{Hg}$ contamination in a fruitful academic cooperation with Rondonia Federal University. These were maintained 'freeze-dried' for the last 20 years.

The studies with DDT and PCBs started around 1998 and were supported in part by The Mount Sinai School of Medicine (New York, USA). Huge man-made lakes from hydroelectric power plants located in three different Amazonian States (Amazonas, Balbina reservoir; Pará, Tucurui reservoir and Rondonia, Samuel reservoir) were also visited between 1995 and 2005 .

The following certified materials were used (NISTSR1588, Cod Liver Oil). The Radioisotopes Laboratory participated with good $\mathrm{Z}$ scores in IAEA intercomparison using IAEA435 (Tuna fish). For the analyses of organochlorine pesticides and PCB congeners, conventional and modified Sohxlet extraction using non-polar solvents were employed.

Total mercury levels were measured using cold vapour atomic absorption methods after oxidative digestion using $\mathrm{HNO}_{3}$ and $\mathrm{H}_{2} \mathrm{SO}_{4}$ followed by a reduction of the samples with sodium borohydride.

For abiotic materials, especially for river bottom sediment samples a desulfurization method based on the Jensen reaction was developed after Japenga et al. ${ }^{4}$

Milk samples were extracted using C-18 SPE and Florisil cartridges using a Supelco vaccum manifold. 
The extracts were submitted to an acid clean-up using concentrated sulfuric acid. We used a Shimadzu GC$14 \mathrm{~B}$ with $60 \mathrm{~m}$ capillary DB-5 column coupled to a ${ }^{63} \mathrm{Ni}$ electron capture detector (ECD). Identification was based on the relative retention times using octachloronaphtaleneOCN as an internal standard, which was also used for quantification based on calculated standard solutions response factors.

\section{Results and Discussion}

Soils

The concentrations of $\Sigma \mathrm{DDT}\left(o, p^{\prime}-\mathrm{DDE}+p, p^{\prime}-\mathrm{DDE}+\right.$ $p, p$ '-DDD $+o, p$ '-DDT $\left.+p, p^{\prime}-\mathrm{DDT}\right)$ in house soils varied from 2.0 to $55.4 \mathrm{ng} \mathrm{g}^{-1}$ while in forest soils the values obtained were between 1.6 and $13.3 \mathrm{ng} \mathrm{g}^{-1}$. The $p$, $p^{\prime}$-DDD/ $p, p$ '-DDE ratios for house soils (mean $=3.85$ ) and for forest soils $($ mean $=1.87$ ) were high when we compare these results to a previous work ${ }^{5}$ at a location with a known history of DDT utilization, where surface soils collected in rural areas of Jacarepagua, located in Rio de Janeiro city, showed ratios of 0.06 (1997) and 0.09 (1999).

Our study confirms the previous work of Parr and Smith ${ }^{6}$ and Ramesh et al. ${ }^{7}$ that had demonstrated that the DDT degradation to DDD is mediated by anaerobic bacteria and fungi working in reductive environments, that may be the case of the Amazon soils during the rainy season. The DDT/DDE ratio can be used as an estimate of the time trend of DDT application.

In the present study of Puruzinho Lake we have found mean ratios of 1.86 for house soils and 0.85 for forest soils. The mean value for the soil of the houses is similar to the ones found by Vieira et al.,$^{5} 1.91$ in 1997 and 1.19 in 1999. However these results are higher than the previous ratios reported by Torres et al., ${ }^{8}$ in a study of urban soils collected in some towns along the Madeira river. These high ratios may be due to recent reported uses of DDT against termites that commonly attack the local wooden houses. The DDT concentrations in both forest and house soils are irregularly distributed, showing a somewhat erratic behavior of pesticide application in the study area.

\section{DDT in Amazonian fish (1990-2002)}

As the fish samples come from very different locations and may have different food habits, the results presented here must be interpreted with caution. However, such an approach may be considered as 'eye-opening', since a somewhat decreasing time trend was observed. This is an indicative of DDT clearance in the Amazon fish biota.
As all samples were freeze-dried, the results are in $\mu \mathrm{g} \mathrm{g}^{-1}$ (dry weigth).

The average and standard deviations of total DDT levels are: $1990=49.9 \pm 17.4 ; 1991=54.4 \pm 108.8 ; 1992=20.3 \pm$ $17.9 ; 1993=23.2 \pm 54 ; 1996=10.1 \pm 64.3 ; 2000=3.9 \pm$ $40.2 ; 2002=6.2 \pm 2.5$. The declining trend can be seen in Figure 1 . The vast majority ( $>90 \%$ ) of these samples where collected in the Madeira river watershed.

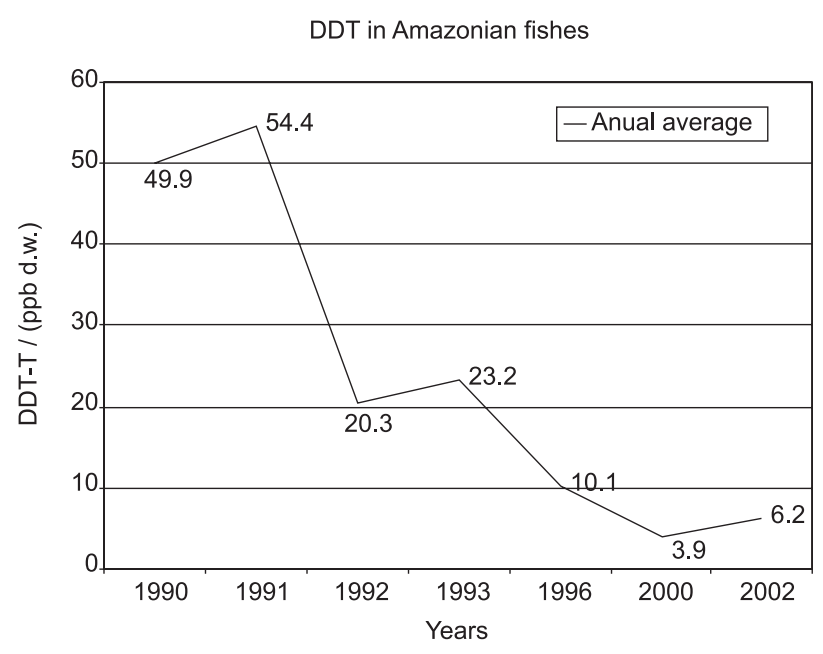

Figure 1. DDT in fish from the Amazon region of Brazil 1990-2002.

\section{DDT in Amazonian breast milk}

All of the chromatograms of the breast milk samples showed residues of DDT and its metabolites in all analysed samples. The concentrations ranged from 10.7 to $7272 \mathrm{ng} \mathrm{g}^{-1}$ of lipid for $p, p^{\prime}$-DDE, from near to the limits of quantification to $400.7 \mathrm{ng} \mathrm{g}^{-1}$ of lipid for $p, p$ '-DDD, from 3.0 to 2534 for $p, p$ '-DDT, and 25 to 9362 for total DDT.

The Figure 2 shows the distribution of the average and geometric means of the total DDT values in the different localities studied. The geometric mean of the total DDT in the different localities studied ranged from 118.3 in Santa Rosa to $1005 \mathrm{ng}$ of total DDT per $\mathrm{g}$ of lipid in Cachoeirinha. The geometric mean of total DDT per $\mathrm{g}$ of lipid from the localities showed a good correlation $(r=0.993)$ with the average values. The geometric mean/average ratio was 0.76 . The overall results on breast milk contamination are expressed in Figure 2.

$H C B, D D T s, P C B s$ and $H g$ in the red dolphin (Inia geoffrensis)

These results are a complementary indication of the overall contamination of this region. The specimen collected at the Madeira River is a juvenile. Table 1 presents 


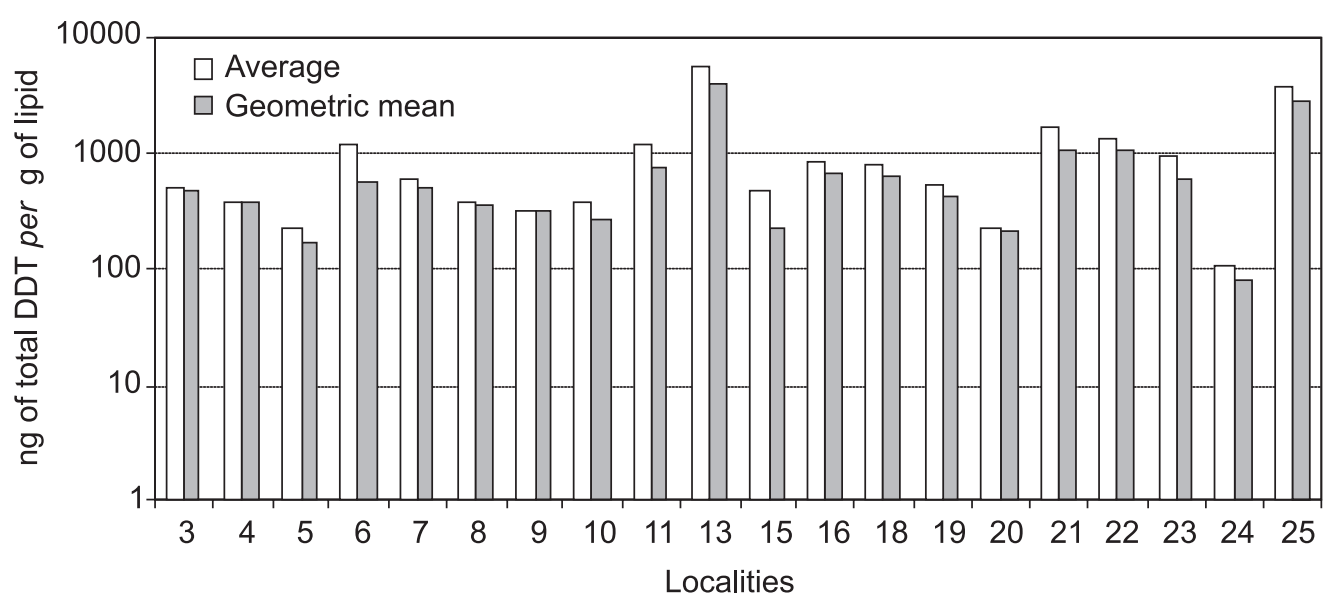

Figure 2. Total DDT in different localities of the Madeira River.

Table 1. Organochlorines $\left(\mu \mathrm{g} \mathrm{g}^{-1}\right.$ lipid) and total $\mathrm{Hg}\left(\mathrm{mg} \mathrm{kg}^{-1}\right.$ liver) in aquatic mammals from the Amazon in Brazil

\begin{tabular}{lcccc}
\hline Rio Solimões (Mamirauá) & $\Sigma \mathrm{DDT}$ & $\Sigma \mathrm{PCB}$ & $\mathrm{HCB}$ & $\mathrm{THg}$ \\
\hline Inia geoffrensis (In1) & 3176 & 1314 & 36 & 2.21 \\
Inia geoffrensis (In2) & 698 & 463 & 9 & 35.9 \\
Inia geoffrensis (In3) & 190 & 151 & 3 & 0.32 \\
Rio Madeira & & & & \\
Inia geoffrensis (In4) & 2430 & 3216 & 6 & - \\
Rio Negro & & & & \\
Sotalia fluviatilis & - & - & - & 215.9 \\
\hline
\end{tabular}

these results in $\mu \mathrm{g} \mathrm{g}^{-1}$ (lipid basis) for the organic pollutants and $\mathrm{mg} \mathrm{kg}^{-1}$ (liver) for total $\mathrm{Hg}$.

All over the world, there are limits for the presence of DDT residues in food items. Most of this legislation follows recommendations developed decades ago, when DDT was considered an innocuous substance setting the limits up to $5 \mathrm{ppm}$ wet weight. Today, new recommendations set $0.3 \mathrm{ppm}$ for poultry meat, keeping the $5 \mathrm{ppm}$ level for other kinds of meat. ${ }^{9}$

The acceptable daily intake of DDT is $<0.025 \mathrm{mg}$ per $\mathrm{kg}$ bw per day. ${ }^{8}$ But as DDT is stored in the fat, the more correct attitude should be to settle limits using fat corrected data. However, in this case, if the fish has a very low fat content, this correction would gender a larger result. What can be said, in this first effort to understand the DDT levels in fish from the Amazon, is that the poor people in the Amazon region, who eat fish every day, were probably eating more DDT in the 80's than they are eating today.

The highest value of total DDT (9361.9 ng of total DDT per $\mathrm{g}$ of lipid) was obtained from a primiparae mother who was 27 years old. Parity is pointed to as a factor in the organochlorine amounts in breast milk. ${ }^{9}$ Lactation is potentially the most significant activity in the reduction of the stored organochlorine in the human body, since a decrease of these compounds was observed during its course. ${ }^{10-14} \mathrm{Age}$ has been noted as one of the most significant contributors to organochlorine pesticides in breast milk. The increase of the concentrations of DDT in breast milk with age has also been observed in other studies. ${ }^{15-17}$

The average $p, p^{\prime}$-DDE/ $p, p^{\prime}$-DDT ratio was 6.3. This means a non-recent use of the insecticide DDT. There is sufficient evidence that the presence of the DDT and its metabolites in the analysed milk samples is due to diets rich in fish, considering that the consumption of contaminated food represents an important source of organochlorine pesticides to humans. ${ }^{9}$

The population living in the Madeira River region is characterised by high consumption of fish in their diet. The presence of DDT observed in previous papers ${ }^{8}$ and high fish consumption can be the source of DDT in the human milk samples studied. Nineteen of the 20 localities presented total DDT contamination ranging from 118 to $771.4 \mathrm{ng}$ of total DDT per g of lipid. Just one locality (Cachoeirinha) presented a geometric mean for total DDT higher than 1000 ng of total DDT per $\mathrm{g}$ of lipid.

\section{Conclusions}

Our data, as well as that gathered from the scientific literature, indicate that the overall per capita consumption of fish can surpass $550 \mathrm{~g}$ of fish per day and this is the main explanation for the high level of residues in breast milk.

Viewed from an urban point of view and even according to Brazilian standards, these populations are clearly poor and most of them may eat basically three fish meals with cassava flour per day. Locally collected native fruits may complement this diet. None of the riverine communities have sanitary systems and the houses are no more than huts constructed of wood and straw. 
Treated potable water does not exist in any part of Amazonian rural settlements and most of this people drink river water after the suspended material is deposited onto the bottom of big plastic or clay canisters.

The average DDT levels in fish are decreasing and human exposure to this compound is declining. However, chronic exposure to low concentrations of organochlorines may represent a particular risk. Due to the long half-lives in the organism, exposure for long periods results in bioaccumulation and occurrence of adverse effects.

Since the organochlorinated compounds studied here, as well as mercury in its methylorganic form are prone to be biomagnified through the aquatic food chain, its determination in cetaceans is of special interest, due to their top position in the aquatic food web and their long life span. Despite the great concern, some cetacean species have not been studied with this approach and to our knowledge, this is probably among the first reports of organohalogen compounds in tissues of Amazon dolphins from Brazil.

\section{Acknowledgments}

CNPq-PPG7 and CNPq-PRONEX 0877 supported this work. C. E. A. e Silva received a $\mathrm{PhD}$ fellowship from CAPES/MEC. Dr. J. P. M.Torres is the Selikoff Advance Fellow at Mount Sinai/Queens College International Training Program of Environmental and Occupational Health and was partly funded by the Fogarty-NIH Grant 1 D43 TW00640.

\section{References}

1. UNEP, United Nations Environmental Program, 2001.
2. Oliveira-Filho, A; Proceedings of the First International Workshop on Organic Micropollutants in the Environment, Rio de Janeiro, Brazil, 1999.

3. IBAMA, Brazilian Ministry of the Environment, 2007.

4. Japenga, J.; Wagenaar, W. J.; Smedes, F.; Salomons, W.; Environ. Tech. Lett. 1987, 8, 9.

5. Vieira, E. D. R.; Torres, J. P. M.; Malm, O.; Environ. Res. 2001, $86,174$.

6. Parr, J. F.; Smith, S.; Soil Sci. 1974, 118, 45.

7. Ramesh, A.; Tanabe, S.; Tatsukawa, R.; Environ. Pollut. 1989, 62,213

8. Torres, J. P. M.; Pfeiffer, W. C.; Markowitz, S.; Pause, P.; Malm, O.; Japenga, J.; Environ. Res. 2002, 88, 134.

9. ANVISA; Brazilian Ministry of Health, Brasilia, Brasil, 2005.

10. Hagyard, S. B.; Brown, W. H.; Stull, J. W.; Whiting, F. M.; Kemberling, S. R.; Bull. Environ. Contam. Toxicol. 1973, 9, 169.

11. Bakken, A. F.; Siep, M.; Acta Pediatr. Scand. 1976, 65, 535.

12. Rogan, W. J.; Gladen, B. C.; McKinney, J. D.; Carreras, N.; Hardy, P; Thullen, J; Tingelstad, J.; Tully, M.; Am. J. Public Health 1986, 76, 172.

13. Skaare, J. A.; Polder, A.; Arch. Environ. Contam. Toxicol. 1990, 19, 640 .

14. Quinsey, P. M.; Donohue, D. C.; Cumming, F. J.; Eur. J. Clin. Nutr. 1996, 50, 438.

15. Stacey, C. I.; Perriman, W. S.; Whitney, S.; Arch. Environ. Health 1985, 40, 102.

16. Mussalo-Rauhamaa. Pyysalo, H.; J. Toxicol. Environ. Health 1988, 25, 1.

17. Dewailly, E.; Ayotte, P.; Laliberté, C.; Weber, J. P.; Gingras, S.; Nantel, A. J.; Am. J. Public Health 1996, 86, 1241.

Received: January 31, 2009 Web Release Date: June 5, 2009 